the acting chairman, upon which comment was then invited. Dr Shapley spoke briefly, and moved the acceptance of the report. The motion was carried.

Mme Roberts presented to the Commission a copy of the second Atlas of Herschel's 52 Nebulous Regions, made from camera charts similar to those included in the first Atlas, and intended for the use of observers with small instruments. This was followed by short reports and suggestions from several of those present. Prof. Lindblad announced that it was intended to apply the new thirty-six inch reflector of the Stockholm Observatory to nebular problems. Dr Adams discussed briefly the bright nova of I93I, with details as to spectrum and absolute magnitude. Dr Carpenter remarked that the work on the Steward Observatory zone was nearly finished. Dr Van de Kamp drew attention to the application of the extra-galactic nebulae in discussing the distribution of dark material in our own system. Dr Oort commented on the connection between the apparent distributions of faint stars and extra-galactic nebulae. Dr Menzel outlined his work on the solution of a generalized form of Milne's special case of radiative equilibrium. He also warned against over-emphasis by the committee of the extra-galactic nebulae, as compared with planetary nebulae, and suggested the creation of a sub-committee to deal with the latter problem. It was decided to refer the question of the appointment of such a sub-committee to the Chairman of the Commission.

Dr Schilt announced that he had been delegated by Commission 27 to request that Commission 28 adopt the following recommendation:

"It is recommended that variable star workers note the importance of more accurate determinations of the epochs of cluster type variables, particularly in globular clusters that have large numbers of variable stars."

The recommendation was adopted.

The acting chairman brought up the question of including our own galaxy in the scope of the Commission's activities. Dr Shapley was of the opinion that the inclusion should be informal, and incidental to the real aims of the Commission.

\title{
Commission 29. (Stellar Classification.)
}

President: Prof. H. N. Russell.

SECRETARY: Dr C. S. Beals.

The Commission held two meetings and the time was taken up almost entirely in a discussion of stellar classification.

Dr J. S. Plaskett moved, seconded by Miss Payne, that a sub-committee be appointed to consider the classification of Wolf Rayet and related spectra.

The committee was appointed as follows: Miss C. H. Payne, Prof. H. H. Plaskett, Dr C. S. Beals, Chairman.

Dr W. S. Adams moved, seconded by Dr J. S. Plaskett, that a sub-committee be appointed to tabulate and bring up to date criteria of classification for both high and low dispersion at present in use throughout the stellar sequence.

The committee was appointed as follows: Miss A. J. Cannon, Dr O. Struve, Prof. H. H. Plaskett, Dr B. Lindblad, Dr W. S. Adams, Chairman.

\section{Commission 30. (RAdIAI Velocities.)}

President: Dr J. S. Plaskett.

Secretary: Dr W. E. Harper.

The Report as printed was discussed section by section. Section I being only a summary of progress was, with the correction of a typographical error, accepted. 
Section III was discussed and, on the motion of Frost and Moore, a sub-committee was appointed by the Chairman consisting of Adams, Moore and Harper, to prepare a suitable list of standard velocity stars for the faint stars and to revise the previous list of standard velocity stars, omitting those now known or suspected to vary slightly in velocity.

In dealing with Section II the Chairman commented on the good work of Moore in preparing the new catalogue of radial velocities, a copy of which was laid on the table, and the following resolution was moved by Adams, seconded by Frost and carried:

"This Commission desires to express to Dr Joseph H. Moore and Mrs Moore its deep appreciation of their work in preparing the General Catalogue of Radial Velocities, for the time and labour which they have devoted to this long and arduous undertaking, and the skill with which they have combined material of the most varied character. The preparation of this catalogue would in itself justify many times over the existence of this Commission."

Dr Moore made suitable reply.

The question of the most suitable epoch for such catalogues was next considered and it appeared to be the unanimous opinion among members and visitors that for many years to come rgoo was the most suitable epoch.

Section IV dealing with the need for an observatory in the southern hemisphere was discussed at length. Adams stated that as soon as conditions permitted the Carnegie Institution would place a roo-inch reflector there, but such would not be for some little time. Moore stated that the Lick Observatory were not considering a second southern expedition and thought the Cape Observatory should be urged to continue radial velocity work. The Chairman mentioned the possibility of the transfer of the Radcliffe Observatory at Oxford to South Africa and called on Knox-Shaw to explain the situation. The Chairman then offered a resolution, relative thereto, which on the motion of Frost supported by Moore was adopted for recommendation to the General Assembly. The resolution was as follows:

"Whereas while many telescopes, including the largest in use, are engaged in radial velocity and other spectroscopic work in the northern sky, while others under construction or projected will probably follow this line also, there is no telescope at present employed or now available for this work in the southern hemisphere. Although the Lick Observatory has completed the radial velocities of stars brighter than magnitude 5.5 over the whole sky by aid of a southern station now discontinued, there are thousands of observations of fainter southern stars required to balance corresponding ones already obtained in the northern hemisphere.

"As a result of this unsymmetrical distribution of observations, many statistical investigations of motions in the stellar system which require homogeneous data are incomplete and the results uncertain for lack of the necessary radial velocities of the southern stars. This need has been particularly felt recently in investigations on the rotation of the galaxy, on the motions and distribution of the cosmic diffuse matter, and on the cause of the mysterious positive residual velocity, the K-term, as well as in many allied problems, none of which can be satisfactorily completed until the lacking southern velocities are available.

"The International Astronomical Union, therefore, earnestly commends any project for obtaining the urgently needed observational data in the southern sky. Particularly, having heard of the project to transfer the Radcliffe Observatory from Oxford to Pretoria, South Africa, and to equip it with a large reflecting 
telescope, the Union welcomes the proposal most heartily as one likely to furnish very material help towards the provision of the desired data and earnestly hopes that nothing may stand in the way of its fulfilment."

From a general discussion of the report of the sub-committee on Co-operation in Radial Velocity Observations it was found to be desirable to have such a committee continued. The Chairman named the same committee members, namely, Moore, Joy and Harper.

General approval was given to the lists of wave-lengths prepared by the subcommittee on wave-lengths but discussion showed the need for further detailed study of the various lines. The Chairman then named the members of this subcommittee to be J. S. Plaskett, Adams, Moore and Struve.

\section{Commission 3I. (BuREAU DE L'HeURE.)}

PREsident: Prof. N. E. Nörlund.

SECRETARY: M. A. Lambert.

Après avoir rappelé le souvenir du Général Ferrié et de M. Bigourdan, décédés au cours de l'année, le Président met aux vœux l'élection du Vice-Président de la Commission, en remplacement du Général Ferrié. A l'unanimité le Général G. Perrier est élu et il est invité par le Président à prendre place au bureau.

Le Président fait connaître qu'il a examiné les comptes du B.I.H. pour les quatre dernières années et que les règlements ont été respectés:

Les dépenses se sont élevées.

Pour l'année I 928 à $64,170,59$ frs.

$$
\begin{aligned}
& \text { I929 à } 66,547,20, \\
& \text { I930 à } 69,367,60,
\end{aligned}
$$

Le total des dépenses pour les années I928-I93I s'élève à 268,94I,24 frs., et le total des recettes est $269,799,95$ frs. Par conséquent la balance au 3 I décembre r93I est $858,7 \mathrm{I}$ frs.

La Commission adopte les conclusions approbatives du Président, qui seront soumises au Comité Exécutif.

Les différents points de l'ordre du jour sont successivement abordés et discutés.

(a) Le Directeur du B.I.H., M. Esclangon, donne lecture de son rapport sur l'activité passée et future du Bureau. Il expose quels services rend, à l'Astronomie, à la Géodésie, à la Physique, la concentration et la discussion des documents horaires provenants du monde entier. L'importance du B.I.H., conclut-il, légitime absolument le maintien intégral de la subvention en livres qui lui était allouée ces dernières années, la dépréciation de cette monnaie constituant déjà, en fait, une amputation notable du budget.

(b) En ce qui concerne l'adoption par tous les Observatoires, démandée par MM. Bianchi, Carnera, Silva, d'un système uniforme de positions d'étoiles fundamentales pour la détermination de l'heure, $M$. Dyson fait remarquer que la question se résoudra d'elle-même d'ici peu. Toutefois, la proposition de M. Silva de signaler dès maintenant ce vœu au Président de la Commission des Éphémérides est adoptée.

(c) La discussion s'ouvre alors sur la proposition, faite par les mêmes membres de la délégation italienne, de réduire la subvention accordée au B.I.H. par l'Union Astronomique et de faire appel à la participation financière de l'Union Géodésique 